WARSZTATY Z GEOGRAFII TURYZMU

ISBN 978-83-7969-262-0 $\quad$ s. 145-159

http://dx.doi.org/10.18778/7969-262-0.10

Katarzyna DUDA-GROMADA

Uniwersytet Warszawski

\title{
W BLASKU CZY W CIENIU METROPOLII? ROZWÓJ PODSTOŁECZNEJ MIEJSCOWOŚCI NA PRZYKŁADZIE KONSTANCINA-JEZIORNY
}

\section{Wprowadzenie}

Mieszkańcy dużych miast niezmiennie wykazują zainteresowanie krótkookresowym wypoczynkiem, który może być realizowany na obszarach znajdujących się w stosunkowo niedalekiej odległości od miejsca zamieszkania. Współcześnie funkcja wypoczynkowa czy rekreacyjna jest jedną z podstawowych funkcji, jakie pełnią miejscowości w strefie podmiejskiej. Na przestrzeni ostatnich kilkudziesięciu lat wielu badaczy z różnych ośrodków naukowych $\mathrm{w}$ Polsce podejmowało tematykę wypoczynku podmiejskiego, co zaowocowało opracowaniami o charakterze empirycznym oraz teoretycznym (por. FARACIK 2006, WŁODARCZYK 2009). Powstały liczne teorie wyjaśniające lokalizację turystyki i rekreacji na obszarach podmiejskich. Wyczerpujący przegląd tworzonych na gruncie geografii turyzmu modeli lokalizacji tego zjawiska znajduje się w opracowaniu A. KOWALCZYKA (1993). Większość z nich zakładała przede wszystkim duże znaczenie walorów środowiska przyrodniczego $\mathrm{w}$ procesie zaspokajania potrzeb turystyczno-wypoczynkowych mieszkańców dużych miast (np. Christaller 1955, za: KoWALCZYK 1993), ale również obecność bazy rekreacyjnej (np. CLAWSON, HELD, STODDARD 1960). Niektórzy badacze w swoich rozważaniach i pro- 
wadzonych badaniach uwzględniali także subiektywne preferencje osób wypoczywających, ich percepcję środowiska oraz doświadczenia (np. Miossec 1977, za: KOWALCZYK 1993). Ważnym zagadnieniem była również delimitacja wypoczynkowej strefy podmiejskiej. W niektórych opracowaniach ich autorzy określali wielkość strefy wypoczynku, jej zasięg i granice (por. KoWALCZYK 1993). W przypadku strefy podmiejskiej Warszawy B. KRÓL (1968) wyróżnił cztery koncentryczne strefy:

1) przymiejską - do $25 \mathrm{~km}$, wypoczynek codzienny dalszy oraz weekendowy;

2) podmiejską bliską - do $50 \mathrm{~km}$, przede wszystkim wypoczynek weekendowy, ale również sezonowy (urlopowy) bliskiego zasięgu;

3) podmiejską dalszą - do $75 \mathrm{~km}$, przede wszystkim wypoczynek sezonowy (urlopowy) oraz weekendowy dłuższy (1,5-2,5 dnia);

4) dalszego zasięgu - wypoczynek sezonowy, w małym stopniu weekendowy dalszego zasięgu.

Jednym z wielu miast, ale o wyjątkowym charakterze, które znajduje się w strefie wypoczynku podmiejskiego Warszawy jest Konstancin-Jeziorna. Jego wyjątkowość związana jest przede wszystkim z faktem, iż jako jedyne miasto w województwie mazowieckim ma status uzdrowiska. Miasto Konstancin-Jeziorna, liczące w 2012 r. 17473 mieszkańców (Bank Danych Lokalnych GUS, www.stat.gov.pl), znajduje się na południe od Warszawy, w powiecie piaseczyńskim, w odległości około $20 \mathrm{~km}$ od centrum stolicy. Te dwa czynniki - uzdrowiskowy charakter oraz położenie na obszarze metropolitalnym Warszawy - w znacznym stopniu determinują określone funkcje turystyczne i rekreacyjne miasta. Ciekawym zagadnieniem jest także znaczenie bliskości stolicy w procesie rozwoju miasta. Dlatego celem niniejszego opracowania jest przedstawienie historii rozwoju Konstancina-Jeziorny ze szczególnym uwzględnieniem jego położenia względem Warszawy. Historię rozwoju miasta Konstancin-Jeziorna od powstania do czasów współczesnych można podzielić na trzy okresy. Poszczególne etapy charakteryzują się występowaniem zjawisk związanych z jednej strony z procesami zachodzącymi wewnątrz miasta (np. parcelacja dóbr i sprzedaż działek), ale z drugiej strony z uwarunkowaniami zewnętrznymi (np. wybuch wojny). 


\section{Etap I rozwoju Konstancina-Jeziorny - lata 1897-1939}

Historia Konstancina pośrednio sięga okresu 1678-1688, kiedy we wsi Obory powstała rezydencja, zbudowana przez kanclerza Jana Wielopolskiego, którego żoną była siostra króla Jana Sobieskiego. Po jego śmierci, najstarszy syn sprzedał dobra w 1738 r., prawdopodobnie Hieronimowi Wielopolskiemu i jego małżonce Urszuli z Potockich, która od roku 1779 została właścicielką dóbr po mężu. W latach 1806-1945 Obory były własnością rodziny Potulickich. W roku 1897 Witold hrabia Skórzewski, będący wykonawcą testamentu ciotki, Marii hrabiny Grzymała-Potulickiej, miał sprzedać fragment dóbr ziemskich, natomiast uzyskane pieniądze przekazać spadkobiercom. Postanowił jednak założyć nad Jeziorką letnisko, które z założenia byłoby przeznaczone dla najbogatszych mieszkańców Warszawy. Warszawa była wówczas dynamicznie rozwijającym się ośrodkiem, w którym z jednej strony zwiększała się liczba ludności, ale $\mathrm{z}$ drugiej strony następował wzrost zamożności jej mieszkańców. Czynniki te spowodowały, że zamożni obywatele, zgodnie z trendami panującymi w ówczesnej Europie, chcieli wznosić okazałe podmiejskie rezydencje. W rezydencjach tych właściciele mieli odpoczywać od miejskiej ciasnoty i zgiełku, przyjmować gości, pokazywać swoje bogactwo. Dlatego tereny pod Warszawą były obiektem dużego zainteresowania. Najczęściej odwiedzano Lasek Bielański czy Saską Kępę, która do końca XIX w. pełniła właśnie funkcję podmiejskiego letniska (www. muzeumkonstancina.pl). Działanie hrabiego Skórzewskiego było zatem odpowiedzią na ówczesną sytuację w Warszawie, a przede wszystkim na zapotrzebowanie na tereny podmiejskie w spokojnej, ładnej okolicy. Hrabia notarialnie wydzielił około 110 ha, a następnie zlecił ich podział i sporządzenie planu zagospodarowania. Powstające letnisko nazwał Konstancją (na cześć swej matki Konstancji z Potulickich Skórzewskiej). Powołał Towarzystwo Akcyjne Ulepszonych Miejscowości Letniczych, które następnie zmieniło nazwę letniska na Konstancin i podjęło się dalszej jego rozbudowy. Wydzielone działki można podzielić na dwa rodzaje. Pierwszy z nich to tereny, które przeznaczone zostały do wspólnego użytkowania przez mieszkańców letniska i gości. Około 10 ha lasu i polanek przeznaczono na założenie nowego parku angielskiego z klombami i dywanami kwiatowymi (HERTEL 1997). W parku powstała restauracja Casino, w stylu nadbałtyckich kurhausów - drewniana i elegancka (rys. 1). Drugi rodzaj działek stanowiły parcele przeznaczone do sprzedaży i budowy willi, które miały powierzchnię blisko 3,3 tys. $\mathrm{m}^{2}$, a wydzielono ich około 260 . 


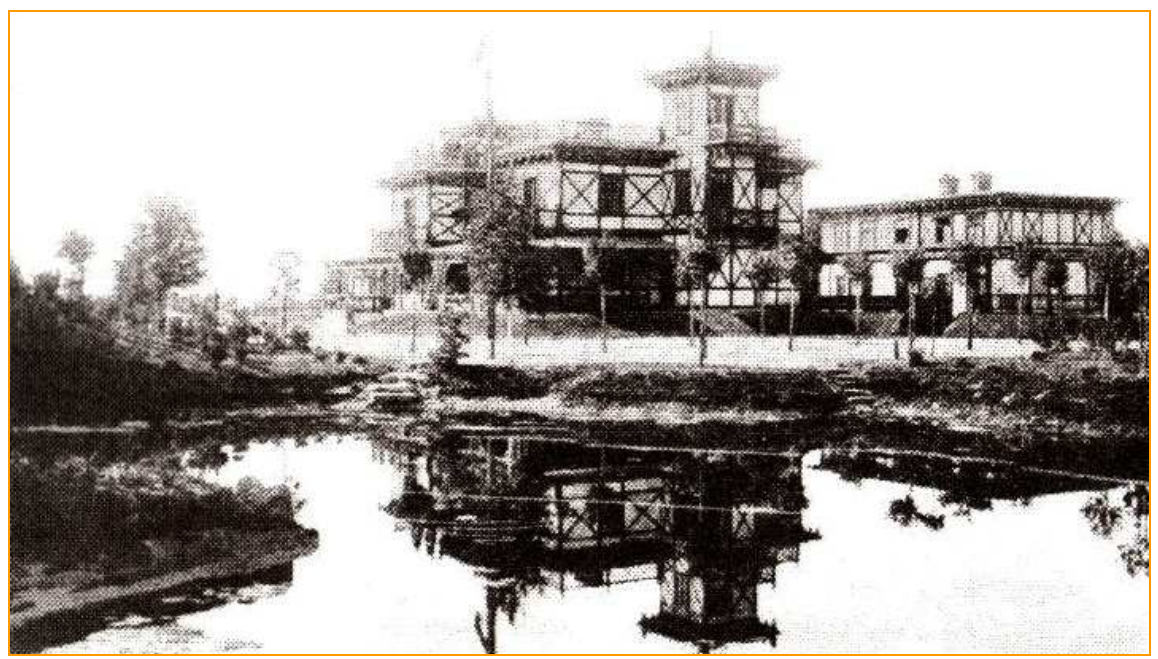

Rys. 1. Restauracja Casino w Konstancinie, 1901 r.

Źródło: „Tygodnik Ilustrowany”, 1901 r. (www.muzeumkonstancina.pl)

Zaczęły powstawać pierwsze wille budowane przez zamożnych mieszkańców Warszawy, którzy - jak wspomniano wcześniej - chcieli mieć tutaj swoje letnie rezydencje. Wówczas zabudowa odbywała się pod ścisłym nadzorem Towarzystwa, które zadbało o stylowość i elegancję Konstancina. Wprowadzono rygorystyczne przepisy, m.in.:

- parceli nie wolno było dzielić;

- na każdej można było zbudować tylko jeden budynek mieszkalny, który musiał mieć cztery ściany frontowe, a jego dopuszczalna wysokość wynosiła dwa piętra, minimalna odległość od ulicy 20 łokci (ok. $11 \mathrm{~m}$ ), a od terenów sąsiednich 10 łokci;

- budynki gospodarcze musiały spełniać standardy pod względem estetycznym;

- zabronione było prowadzenie fabryk, zakładów przemysłowych, gastronomicznych i innych przedsiębiorstw dochodowych.

Zabudowa z tego okresu charakteryzuje się bogactwem wzorów (pałacyki, dwory, zameczki rycerskie), a projektantami byli sławni i wybitni architekci z Warszawy. Rezydencje otoczone były pięknie utrzymanymi ogrodami oraz drewnianymi lub metalowymi ogrodzeniami ze stylowymi furtkami i bramami. Ulice Konstancina, które nazywano alejami, wytyczane były w linii prostej, bez zakrętów (rys. 2). 


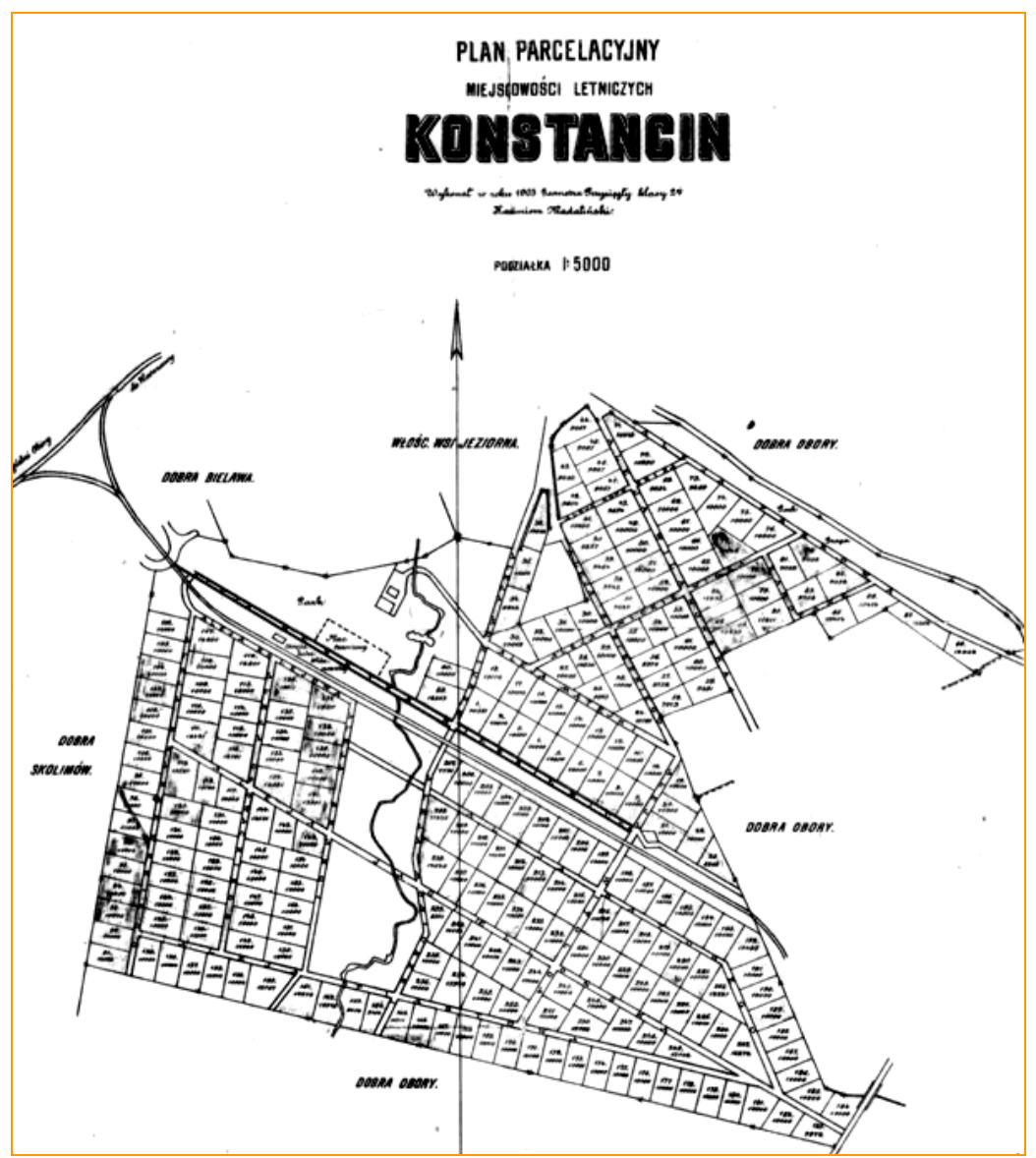

Rys. 2. Plan parcelacji Konstancina, 1900 r.

Źródło: www.muzeumkonstancina.pl

Warto również wspomnieć o zapewnianiu ciszy wypoczywającym, czemu służyć miały zarządzenia:

- Zakaz wjazdu na teren letniska wszelkim pojazdom w godzinach od zmroku do późnego ranka. Uzasadnienie: letnicy sypiają z reguły przy otwartych oknach, aby wdychać przez sen żywiczne, leśne powietrze, musi przeto panować przez całą noc niczym nie zakłócona cisza. Aby temu zakazowi nadać pełną egzekutywę, ustawione były na drogach dojazdowych do letniska szlabany zamykane na noc.

- Zakaz wstępu na teren letniska Żydom. Jak się domyślamy, nie był to żaden rasistowski wybryk hrabiego, lecz najprostsze określenie hand- 
larza-domokrążcy, mogącego również zakłócać wypoczynek mieszkańcom willi i pensjonatów" (ORTHWEIN 1969, s. 35).

Ważnym wydarzeniem w historii Konstancina było przedłużenie do letniska linii wąskotorowej Kolejki Wilanowskiej (1898). Dzięki temu letnisko zostało włączone do podmiejskiego układu komunikacyjnego, co umożliwiło bezpośrednie połączenie ze stolicą. Było to dużym atutem, podkreślanym nawet w ogłoszeniach (rys. 3).

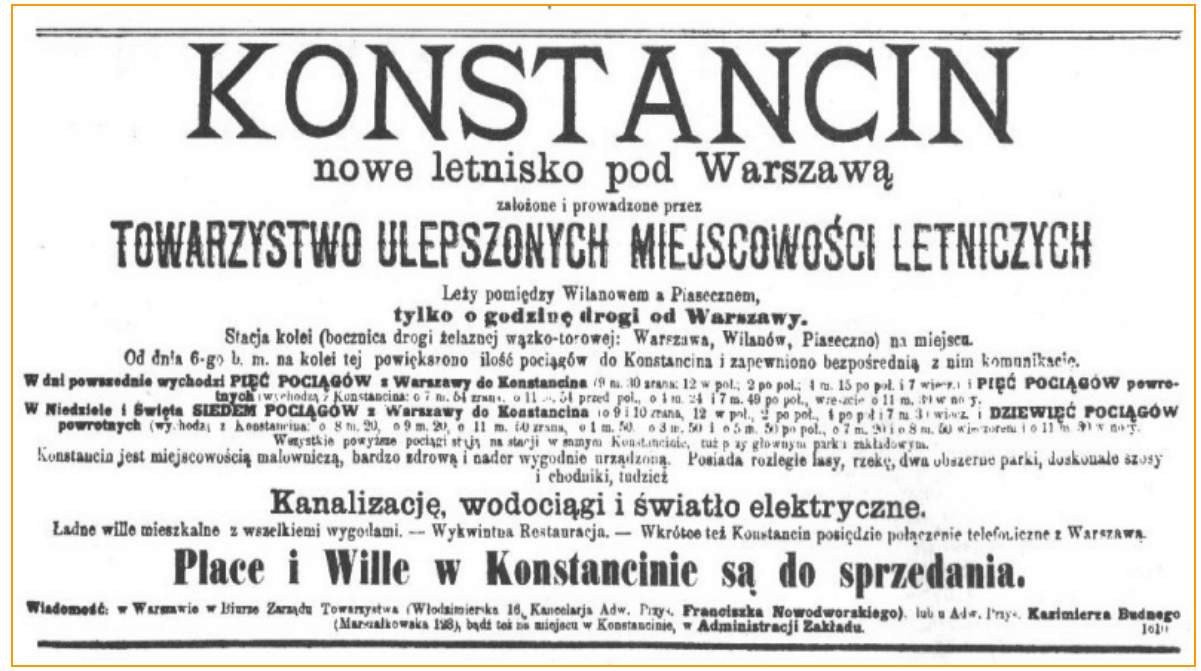

Rys. 3. Ogłoszenie w „Kurierze Warszawskim”, 1901 r.

Źródło: www.muzeumkonstancina.pl

Powstałe liczne obiekty - rezydencje - dzieła oryginalne wybitnych ówczesnych architektów zadecydowały o charakterze Konstancina jako reprezentacyjnej, stylowej miejscowości podstołecznej. Wodociąg i kanalizacja, elektryfikacja domów i alei, nowe wille, ogrody, skwery, tętniące życie towarzyskie. Konstancin bez wątpienia stał się najbardziej nowoczesną i kulturalną miejscowością podstołeczną (HERTEL 1997). Dzięki temu, pomimo dość rygorystycznego regulaminu i stosunkowo wysokiej ceny większość działek została sprzedana do wybuchu pierwszej wojny światowej.

Opisane czynniki spowodowały, że Konstancin już przed I wojną światową stał się luksusowym kurortem. Towarzystwo Akcyjne Ulepszonych Miejscowości Letniczych zostało rozwiązane w 1917 r., a jego obowiązki względem Konstancina przejął Zarząd Osady Konstancin. I wojna światowa 
nie spowodowała żadnych szkód, a wręcz przeciwnie - nadal odbywały się koncerty, a życie towarzyskie tętniło. Wydarzenia, które miały miejsce w okresie międzywojennym i związane $z$ nimi zubożenie społeczeństwa spowodowały, że niektórzy właściciele willi, nie mieli środków na ich utrzymanie. Sytuacja ta była przyczynkiem do budowy pensjonatów, których gośćmi mieli być średnio-zamożni mieszkańcy Warszawy.

W roku 1926 dokonano kolejnej parcelacji dóbr oborskich, które znajdowały się na Królewskiej Górze (na południe od ówczesnego Konstancina). Spowodowało to wzrost liczby działek do zabudowy, a zatem wzmożony ruch budowlany i powstanie nowych inwestycji. Wzniesiono tu m.in. luksusową rezydencję Gustawa Wertheima, położoną na terenie 18 parceli o powierzchni około 14 ha. Założenie składało się z budynku mieszkalnego, obiektów pomocniczych, parku oraz basenu.

\section{Etap II rozwoju Konstancina-Jeziorny - lata 1939-1989}

Podczas II wojny światowej władze okupacyjne zajęły kilka bardziej reprezentacyjnych willi. Etapowe wysiedlenia mieszkańców przez Niemców w 1944 r. spowodowały ograbienie rezydencji przez żołnierzy oraz chłopów z okolicznych wiosek. W wyniku dekretów nacjonalizacyjnych po 1948 r. tylko nieliczne nieruchomości były własnością przedwojennych właścicieli (ŚWIĄTEK 2007). Wykorzystali to lokatorzy, w tym bezdomni mieszkańcy Warszawy, którzy bez większych trudów zasiedlili wybrane budynki. $\mathrm{Z}$ czasem uprawomocnili swoje mieszkania. $\mathrm{W}$ ten sposób nastąpiło rozdrobnienie lokali mieszkaniowych oraz zmiana ich przeznaczenia - z pięknych, luksusowych willi, rezydencji letnich na małe mieszkania zwykłych ludzi. Konsekwencją takich działań było obniżenie poziomu kultury społecznej oraz postępująca degradacja zabytkowych obiektów. Ponadto powojenne migracje ludności oraz inicjatywy związane z budownictwem mieszkaniowym zapoczątkowały zmianę wizerunku Konstancina.

$\mathrm{Na}$ początku działalności fabryki większość robotników wynajmowała stancje w pobliskiej Jeziornie i Bielawie. Dynamiczny rozwój przedsiębiorstwa, wynikający z przeniesienia Mirkowskiej Fabryki Papieru, spowodował konieczność budowy osiedla przyzakładowego dla robotników. Wybudowano pięć domów dla robotników, jeden dla inżynierów i urzędników, szkołę, ośrodek zdrowia, aptekę, Dom Ludowy oraz kościół. Należy pod- 
kreślić, że jest to wyjątkowe przyfabryczne założenie urbanistyczne, które zachowało się $\mathrm{w}$ pierwotnym stanie, co bez wątpienia ma dużą wartość architektoniczną oraz historyczną i może stać się ważną atrakcją turystyczną współczesnego miasta. Oprócz zbudowania dla swoich pracowników osiedla, Mirkowska Fabryka Papieru udzielała im także długoterminowych kredytów na dogodnych warunkach, aby ułatwić budowanie przez nich domków jednorodzinnych. Przesłanką takiej polityki finansowej było utrzymanie wykwalifikowanej i przeszkolonej siły roboczej. W kolejnych latach rozwoju przedsiębiorstwa, po nacjonalizacji zakładu, pojawiły się nowe inwestycje. Powstały obiekty rekreacyjne oraz spółdzielcze osiedle mieszkaniowe (por. tab. 1). Dodatkowo w okolicach Piaseczna powstały Zakłady Lamp Nadawczych i Zakłady Lamp Oscyloskopowych, które podobnie jak fabryka papieru potrzebowały robotników. Według badań przeprowadzonych w strefie podmiejskiej Warszawy, pod koniec lat 80. XX w., tereny przemysłowe, osadnicze i komunikacyjne zajmowały w Konstancinie $27 \%$ powierzchni miasta. Ponadto w całej gminie Konstancin-Jeziorna 2973 osoby zatrudnione były w przemyśle i rzemiośle przemysłowym, co stanowiło 3\% zatrudnionych $\mathrm{w}$ tej dziedzinie w całej strefie podmiejskiej Warszawy. Dominował oczywiście przemysł papierniczy, który skupiał $46 \%$ zatrudnionych w przemyśle i rzemiośle przemysłowym w mieście (WIELOŃSKI i in. 1990). Procesy te doprowadzily do zmiany postrzegania Konstancina - letnisko, będące swoistym hotelem dla Warszawy, traktowane było jako miasto, w którym mieszkali pracownicy lokalnego przemysłu. Zostało to nawet zasygnalizowane w warszawskiej prasie. W maju 1949 r. w "Stolicy” napisano, że Konstancin przemieniał się $\mathrm{z}$ letniska snobów w osiedle służące ludziom pracy (www.muzeumkonstan cina.pl). Natomiast nieruchomości, które znajdowały się na Królewskiej Górze zostały przeznaczone dla partyjnych towarzyszy. Dzielnicę ogrodzono i strzeżona była przez Wojska Korpusu Bezpieczeństwa Wewnętrznego. W latach 1948-1956 okazała willa Wertheima stanowiła rezydencję prezydenta Bolesława Bieruta.

W roku 1948 z istniejącej infrastruktury szpitalnej powstał Szpital Chirurgii Kostnej, z którego w 1953 r. utworzono Stołeczne Centrum Rehabilitacji Stocer. W kolejnych latach powstały w Konstancinie szpitale i ośrodki, w których leczono przede wszystkim schorzenia reumatologiczne, neurologiczne, kardiologiczne, a także sanatoria. W 1965 r. odkryto solankę konstancińską, która cztery lata później została uznana przez Ministra Zdrowia za wodę leczniczą. W roku 1967 Minister Zdrowia uznał Konstancin za miejscowość uzdrowiskową i powołał Uzdrowisko Konstancin z siedzibą w Warsza- 
wie (następnie przeniesioną do Konstancina). W końcu lat 70. w związku z wybudowaniem tężni, wprowadzono leczenie schorzeń gardła i dróg oddechowych oraz nadciśnienia. Lokalizacja pod Warszawą podnosiła rangę uzdrowiska.

Tabela 1. Najważniejsze wydarzenia w historii fabryki papieru w Mirkowie

\begin{tabular}{|c|c|}
\hline Rok & Wydarzenie \\
\hline 1776 & $\begin{array}{l}\text { przystosowanie istniejącego na rzece Jeziorce młyna zbożowego do produkcji } \\
\text { papieru przez Jana Józefa Feliksa barona Kurtza (wiedeńskiego aktora, który } \\
\text { mieszkał w Polsce) }\end{array}$ \\
\hline $1778-1790$ & $\begin{array}{l}\text { rozbudowa przez Fryderyka Thiessa, właściciela składu materiałów piśmiennych } \\
\text { w Warszawie, który przejął od Kurtza młyn papierniczo-zbożowy } \\
\text { inwestycje spowodowały, że w ciągu dwóch lat stary młyn stał się manufakturą }\end{array}$ \\
\hline do 1830 & fabryka prowadzona przez różnych przedsiębiorców \\
\hline 1830 & przejęcie fabryki przez Bank Polski \\
\hline 1838 & $\begin{array}{l}\text { uruchomienie pierwszej na terenie Królestwa Polskiego maszyny do wyrobu } \\
\text { papieru, którą sprowadzono z Anglii }\end{array}$ \\
\hline 1843 & zainstalowanie maszyny parowej \\
\hline 1850 & $\begin{array}{l}\text { kierownikiem zostaje Henryk Segno, następuje modernizacja procesu } \\
\text { produkcyjnego }\end{array}$ \\
\hline 1869 & $\begin{array}{l}\text { właścicielami zostają Joanna i Karol Roesslerowie, kapitaliści pochodzenia } \\
\text { czeskiego }\end{array}$ \\
\hline 1887 & $\begin{array}{l}\text { przejęcie przez Towarzystwo Akcyjne Mirkowskiej Fabryki Papieru spod } \\
\text { Wieruszowa, główni udziałowcy to członkowie rodzin Kronenbergów oraz } \\
\text { Natansonów }\end{array}$ \\
\hline 1929 & udział Kronenberga zostaje wykupiony przez Belgów \\
\hline 1936 & udział Belgów wykupiony przez polską spółkę Herbewo \\
\hline 1944 & ogromne zniszczenia \\
\hline 1946 & nacjonalizacja zakładu - powstanie Warszawskich Zakładów Papierniczych \\
\hline 1949-1960 & $\begin{array}{l}\text { pierwsze większe inwestycje o charakterze socjalnym (stadion, pawilon sportowy, } \\
\text { bloki mieszkalne na Grapie) }\end{array}$ \\
\hline 1995 & udziały przedsiębiorstwa wniesione do Narodowych Funduszy Inwestycyjnych \\
\hline $\begin{array}{l}\text { styczeń } \\
1998\end{array}$ & $\begin{array}{l}\text { wykupienie udziałów Warszawskich Zakładów Papierniczych przez fińską Metsa } \\
\text { - Tissue }\end{array}$ \\
\hline $\begin{array}{l}\text { grudzień } \\
1998\end{array}$ & najstarsza część zakładu wykupiona przez Konstans Sp. z o. o. \\
\hline 2010 & zatrzymanie produkcji przez spółkę Konstans \\
\hline 2012 & przeniesienie produkcji do zakładu w Krapkowicach przez firmę Metsa-Tissue \\
\hline
\end{tabular}

Źródło: opracowanie własne na podstawie K. ORTHWEIN (1969, s. 27-33), K. DUDA-GROMADA (2009) oraz www.konstans-papier.com.pl, www.muzeumkonstancina.pl. 
Pod koniec lat 80. ogólnodostępna baza noclegowa ograniczała się do jednego pensjonatu na osiem miejsc noclegowych. Ponadto znajdowały się dwa domy pracy twórczej (80 miejsc noclegowych) oraz osiem szpitali uzdrowiskowych (241 łóżek) i sanatorium (110 łóżek). Dodatkowo, na terenie gminy było w 1987 r. 583 „drugich domów” (JASINSSKI, KOWALCZYK 1990).

\section{Etap III rozwoju Konstancina-Jeziorny - po 1989 roku}

Zmiany ustrojowe, jakie miały miejsce w Polsce po roku 1989, sprawiły, że Konstancin ponownie stał się obiektem zainteresowań zamożnych osób, w tym mieszkańców Warszawy. Nastąpiła swoista „moda na Konstancin”, a posiadanie domu w Konstancinie stało się symbolem prestiżu i dowodem bogactwa. Niektórzy nabywali działki w Konstancinie stawiając na nich często ogromne rezydencje, $\mathrm{z}$ murowanymi ogrodzeniami. $\mathrm{W}$ ten sposób powstały "dzielnice" willowe ze współczesną zabudową. Spacerując tam ulicami mijamy kolejne szczelne ogrodzenia, czasami z daleka widząc część rezydencji. W ten sposób w Konstancinie widoczne jest współistnienie „dwóch światów”, których przedstawiciele rzadko się ze sobą spotykają. Jedną grupę stanowią zamożni obywatele, mieszkający $\mathrm{w}$ ogrodzonych, luksusowych willach, które opuszczają zwykle w celu udania się do Warszawy. Druga grupa to mieszkańcy osiedli mieszkaniowych.

Warto wspomnieć, że część nieruchomości wraz z zabytkowymi willami została wykupiona przez prywatnych właścicieli i wyremontowana zachowując swój charakter. Takimi pozytywnymi przykładami mogą być wille Pallas Athenae, Kaprys, Zagłobin. Jednak zdarzają się również przypadki, niestety dość liczne, kiedy zabytkowe wille popadają w ruinę. Właściciele, poprzez zaniechanie, brak funduszy na inwestycje, a czasami przez celowe działanie, utrzymują budynki w złym stanie technicznym, aż zostaną one zakwalifikowane do rozbiórki. Za przykład niech posłuży willa Zbyszek. Na terenie Konstancina można również znaleźć przykłady wykorzystania obiektów zabytkowych w celach usługowych. Najbardziej znana jest Stara Papiernia - centrum handlowo-usługowo-kulturalne. Obiekt ten powstał w 2002 r. w wyniku rewitalizacji budynków szmaciarni fabryki papieru. Warto nadmienić, że realizacja ta służy jako dobry przykład wykorzystania pofabrycznego obiektu. 
Jak wskazują badania atrakcyjności turystyczno-rekreacyjnej Konstancina-Jeziorny, najbardziej atrakcyjna jest centralna część miasta (DUDA-GROMADA, DURYDIWKA 2013). Jest to związane przede wszystkim z nagromadzeniem obiektów zabytkowych, które powstały na przełomie XIX i XX w. oraz z lokalizacją Parku Zdrojowego. Dzięki funduszom Unii Europejskiej park ten został zrewitalizowany, a jego modernizacja zakończyła się $\mathrm{w}$ roku 2012. W Parku Zdrojowym znajduje się tężnia solankowa, która niezmiennie cieszy się dużym zainteresowaniem. Ponadto powstał amfiteatr, w którym w okresie letnim odbywa się wiele imprez kulturalnych i koncertów, a także system alejek, pomostów i drewnianych kładek, umożliwiających spacerowanie $\mathrm{w}$ mało dostępnych miejscach, na terenach podmokłych, które znajdują się w sąsiedztwie rzek Jeziorki oraz Małej.

Ważnym zagadnieniem związanym ze współczesnym rozwojem Konstancina jest jego uzdrowiskowy charakter. Posiadanie statusu uzdrowiska warunkuje możliwości rozwoju przestrzennego oraz proces zagospodarowywania miasta. Stawia wiele ograniczeń z tym związanych, ale jednocześnie może być powodem do dumy, zwłaszcza że jest to jedyne uzdrowisko w województwie mazowieckiem. Władze lokalne oraz mieszkańcy Konstancina stoją na stanowisku, że głównym celem jest kontynuacja rozwoju funkcji uzdrowiskowej miasta, a przede wszystkim jej utrzymanie. Zdarzają się również opinie przeciwstawne, zwłaszcza $\mathrm{w}$ środowisku lokalnych przedsiębiorców i rolników, którzy z uwagi na uzdrowiskowy charakter gminy (a gmina jest miejsko-wiejska) nie mają swobody w prowadzeniu działalności gospodarczej lub rolniczej.

Istotnym wydarzeniem, które budziło i wciąż budzi liczne kontrowersje, ale przede wszystkim obawy przed przyszłością, jest prywatyzacja spółki uzdrowiskowej Konstancin Zdrój, która została sfinalizowana 9 grudnia 2011 r. Dwa lata od prywatyzacji niewiele się zmieniło, jednak nowy właściciel rozpoczął budowę nowoczesnego obiektu „Konstancińskie Centrum Hydroterapii", który jest zlokalizowany w Parku Zdrojowym, naprzeciw tężni, a jego otwarcie planowane jest latem 2015 r. Zapowiadane są również kolejne inwestycje, przede wszystkim modernizacja istniejących szpitali: rehabilitacyjnego i kardiologicznego.

Powyższe rozważania wskazują jednoznacznie, że Konstancin-Jeziorna jest miastem atrakcyjnym pod względem turystycznym i rekreacyjnym. Natomiast położenie w obrębie obszaru metropolitalnego Warszawy ma duży wpływ na charakter występującego ruchu turystycznego. Wśród odwiedzających można wskazać na dwie grupy. Pierwszą z nich stanowią kura- 
cjusze, którzy przyjeżdżają do funkcjonujących na terenie Konstancina placówek w celach zdrowotnych. Drugą grupą są osoby przyjeżdżające najczęściej w weekendy na jednodniowe wycieczki. Są to przede wszystkim mieszkańcy Warszawy zainteresowani walorami turystycznymi Konstancina, zwłaszcza Parkiem Zdrojowym z tężnią solankową oraz Starą Papiernią.

Biorąc pod uwagę zaprezentowaną historię rozwoju Konstancina-Jeziorny oraz współczesną sytuację miasta, można przedstawić jego układ funkcjonalno-przestrzenny (rys. 4).

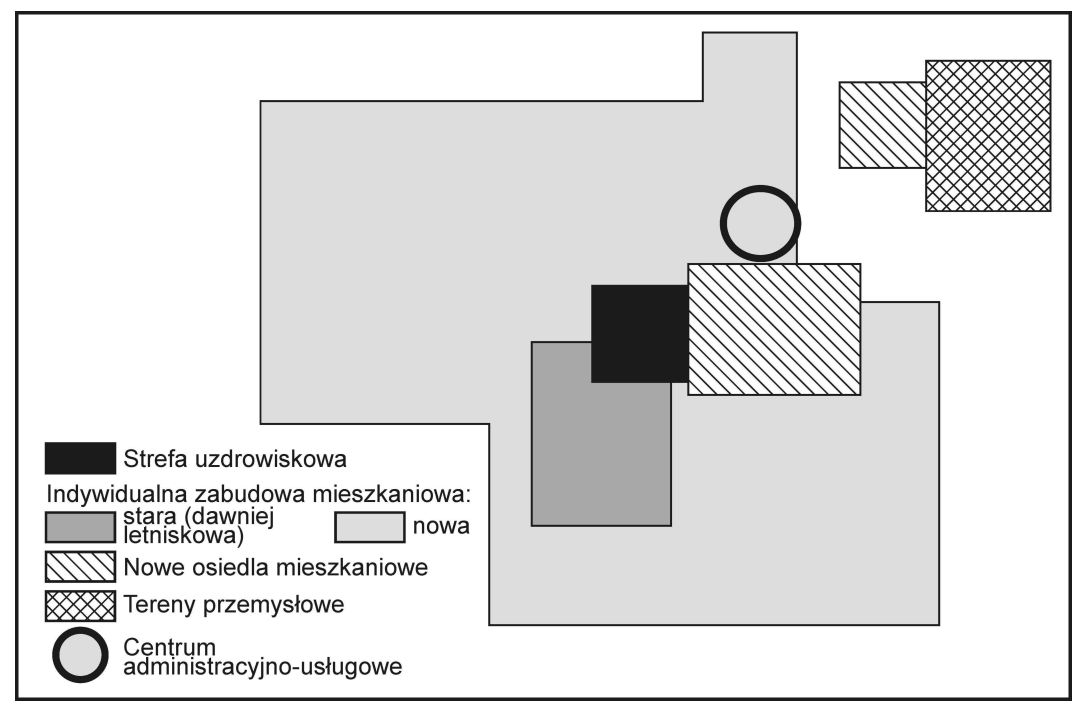

Rys. 4. Model funkcjonalno-przestrzenny Konstancina-Jeziorny Źródło: A. KOWALCZYK, K. DUDA-GROMADA (2009, s. 25)

Centrum układu stanowi strefa uzdrowiskowa wraz z Parkiem Zdrojowym oraz przylegającą od południa strefą indywidualnej starej zabudowy mieszkaniowej. Od strony wschodniej przylega do strefy uzdrowiskowej strefa nowych osiedli mieszkaniowych. Bardziej na północ znajduje się tzw. centrum administracyjno-usługowe, gdzie zlokalizowany jest Urząd Miasta i Gminy. Wszystkie omówione strefy otoczone są dookoła indywidualną nową zabudową. Trochę na obrzeżu, we wschodniej części miasta, znajdują się tereny o charakterze przemysłowym z sąsiadującymi osiedlami mieszkaniowymi. Tutaj zlokalizowana jest niedziałająca już fabryka papieru. 


\section{Zakończenie}

Pracę około istotnie estetycznego i, śmiało rzec można, wspaniałego ozdobienia Konstancina podjęło Towarzystwo akcyjne urządzania ulepszonych miejscowości letniczych już $\mathrm{w}$ roku 1899, a praca ta była prawdziwie intensywna, skoro stworzyła zakątek, stojący na wyżynie wymagań europejskich, stworzyła miejscowość letniczą, jedyną w swoim rodzaju w Królestwie Polskiem, a tem przede wszystkiem przewyższającą wszystkie inne podobne, że znajduje się tuż pod Warszawą („Wieś Ilustrowana”, 1910, s. 44).

Na każdym etapie rozwoju Konstancina-Jeziorny położenie względem Warszawy miało istotne znaczenie. Jednak biorąc pod uwagę rozważania zaprezentowane w niniejszym rozdziale można wskazać okresy, w których bliskość Warszawy miała większe bądź mniejsze znaczenie $\mathrm{w}$ procesie rozwoju miasta (tab. 2).

Tabela 2. Znaczenie położenia Konstancina-Jeziorny względem Warszawy w poszczególnych etapach rozwoju miasta

\begin{tabular}{|c|l|c|}
\hline \multicolumn{1}{|c|}{ Okres } & \multicolumn{1}{|c|}{ Cechy charakterystyczne } & $\begin{array}{c}\text { Znaczenie położenia } \\
\text { względem Warszawy }\end{array}$ \\
\hline & - powstanie letniska, \\
1897-1939 r. & $\begin{array}{l}\text { proces sprzedaży i zabudowywania poszcze- } \\
\text { gólnych działek, } \\
\text { powstanie letnich rezydencji mieszkańców } \\
\text { Warszawy }\end{array}$ & duże \\
\hline $1939-1989$ r. & - rozwój przemysłu papierniczego, \\
& - napływ i wzrost znaczenia klasy robotniczej & małe \\
Od 1989 r. & - "sypialnia" Warszawy, & duże \\
& - postępująca zabudowa, & \\
\hline
\end{tabular}

Źródło: opracowanie własne.

Sam pomysł powstania letniska związany był z rozwojem Warszawy i popytem na działki w strefie podmiejskiej. Zatem w pierwszym okresie, od powstania letniska oraz $\mathrm{w}$ fazie jego zabudowywania mała odległość od stolicy była kluczowym czynnikiem gwarantującym sukces. Zamożni mieszkańcy Warszawy byli nabywcami poszczególnych działek i osobami przyjeżdżającymi do powstałego letniska. Drugi okres rozwoju charakteryzuje się stosunkowo małym znaczeniem odległości Konstancina od Warszawy. Proces rozwoju miasta był wówczas skorelowany z funkcjonowaniem i roz- 
wojem fabryki papieru. Większa część mieszkańców miasta Konstancin była zatrudniona w przemyśle. Na ostatnim etapie rozwoju Konstancina-Jeziorny położenie względem Warszawy ponownie zaczęło odgrywać i wciąż odgrywa znaczną rolę. W tym jednak przypadku można dostrzec zarówno pozytywne, jak i negatywne skutki takiego położenia. Do negatywnych zaliczyć można m.in. postępującą zabudowę, często nieprzystającą do tradycyjnego charakteru miasta, zatłoczenie i wzrost natężenia ruchu samochodowego.

Reasumując można stwierdzić, że Konstancin-Jeziorna od początku istnienia cieszył się dużą popularnością wśród mieszkańców Warszawy jako miejsce krótkotrwałego pobytu, ale również jako miejsce zamieszkania.

\section{LITERATURA}

ClAWSON M., HELD R.B., STODDARD C.H., 1960, Land for the future, John Hopkins Press, Baltimore.

DUdA-GROMADA K., 2009, Ewolucja ładu przestrzennego w uzdrowisku Konstancin-Jeziorna, [w:] Architektura kurortowa, materiały konferencyjne, Szczecin, 309-319.

DudA-Gromada K., DuRYDIWKA M., 2013, Atrakcyjność turystyczno-rekreacyjna miasta Konstancin-Jeziorna, [w:] R. Pawlusiński (red.), Wspótczesne uwarunkowania i problemy rozwoju turystyki, IGiGP UJ, Kraków, s. 375-383.

FARACIK R., 2006, Turystyka w strefie podmiejskiej Krakowa, Instytut Geografii i Gospodarki Przestrzennej, Uniwersytet Jagielloński, Kraków.

HERTEL J., 1997, Znasz-li Konstancin? Stulecie Konstancina 1897-1997.

JASIŃSKI A., KOWALCZYK A., 1990, Zagospodarowanie rekreacyjne obszaru modelowego Konstancin-Jeziorna, [w:] A.S. Kostrowicki (red.), Ksztattowanie układów ekologicznych w strefie podmiejskiej Warszawy, Wyd. SGGW-AR, Warszawa, s. 105-107.

KOWALCZYK A., 1993, Modele lokalizacji wypoczynku podmiejskiego i próba ich zastosowania dla Warszawy, [w:] D. Jędrzejczyk, W. Kusiński (red.), Studia z historii i metodologii geografii ekonomicznej, Wydział Geografii i Studiów Regionalnych, Uniwersytet Warszawski, Warszawa, s. 87-107.

KOWALCZYK A., DUDA-GROMADA K., 2009, Spatial organisation of spa resorts in Poland, „Indian Journal of International Tourism \& Hospitality Research" 3(1), s. 18-27.

KRÓL B., 1968, Wypoczynek podmiejski, turystyka przyjazdowa, „Miasto” 11/12, s. 38-40.

ORTHWEIN K., 1969, Przemiany kulturalne $i$ spoteczne w podwarszawskim osiedlu Skolimów-Konstancin, Wyd. Polskiej Akademii Nauk, Wrocław, Warszawa, Kraków.

ŚWIĄTEK T.W., 2007, Konstancin. Śladami ludzi i zabytków, Wydawnictwo, Pruszków.

WIELOŃSKI A., CETNARSKA H., DURYDIWKA M., DZIAKOWSKA H., JĘDRZEJCZYK D., 1990, Charakterystyka i ocena stosunków społeczno-gospodarczych obszaru modelowego Konstancin-Jeziorna, [w:] A.S. Kostrowicki (red.), Ksztattowanie układów ekologicznych w strefie podmiejskiej Warszawy, Wyd. SGGW-AR, Warszawa, s. 94-102.

„Wieś Ilustrowana”, maj 1910, 3, V, Warszawa.

WŁODARCZYK B., 2009, Przestrzeń turystyczna. Istota, koncepcje, determinanty rozwoju, Wyd. Uniwersytetu Łódzkiego, Łódź.

www.konstans-papier.com.pl; 28.01.2009 r.

www.muzeumkonstancina.pl; $05.10 .2013 \mathrm{r}$.

www.stat.gov.pl; 05.10.2013 r. 


\section{METROPOLITAN GLITTER OR SHADOW? \\ THE DEVELOPMENT OF A TOWN IN THE WARSAW METROPOLITAN AREA \\ ON THE EXAMPLE OF KONSTANCIN-JEZIORNA}

Key words: suburban zone, resort, Konstancin-Jeziorna

\section{Summary}

Short-term vacations in suburban areas enjoy an undiminished popularity. One of the fundamental functions of towns in the suburban zone is their vacation or recreation function. An example of such a town is Konstancin-Jeziorna, located in the suburban vacation zone of Warsaw. Its tourist and recreational functions are $\underline{\underline{\underline{a}}}$ to a large extent, conditioned by its resort character and its location near Warsaw. The aim of this chapter is to present the development of Konstancin-Jeziorna in a dynamical aspect with particular emphasis on its location near Warsaw. The history of the town has been divided into three periods. The author's considerations show that in each individual period the proximity of the capital city was of greater or lesser importance for the development of the town. 